\title{
Analysis of Self-heating of a SiGe HBT Designed for RF Applications According to the Percentage of Germanium
}

\author{
A. Boulgheb*, M. Lakhdara, N. Kherief, S. Latreche \\ Département d'Electronique, Faculté des Sciences de la Technologie, Laboratoire Hyperfréquences \& \\ Semi-conducteurs (LHS), Université des Frères Mentouri, Constantine, Algeria
}

(Received 02 July 2020; revised manuscript received 17 December 2020; published online 25 December 2020)

\begin{abstract}
The main purpose of this paper is to determine the impact of germanium percentage within the base of a SiGe heterojunction bipolar transistor (HBT) in order to analyze the effect of the device self-heating. We use the COMSOL Multiphysics commercial software. The model links the semiconductor module to the HTS (Heat Transfer in Solids) module. This allows to simulate the temperature distribution across the SiGe HBT device for germanium levels ranging from $x=10 \%, 20 \%$ to $x=30 \%$. We first determine the static gain $(\beta)$ of the SiGe HBT by varying the percentages of germanium. In addition, we analyze the heat distribution on the component surface for the three considered levels of germanium in order to record the maximum temperature $T_{\max }$ in the device. Indeed, for $x=10 \%$, the maximum temperature is $T_{\max }=377 \mathrm{~K}$ and is close to the base-collector junction. When the germanium fraction in the SiGe alloy is increased $(x=20 \%)$, the maximum temperature of self-heating decreases $\left(T_{\max }=366 \mathrm{~K}\right)$, while for $x=30 \%$ the temperature of self-heating decreases more $\left(T_{\max }=354 \mathrm{~K}\right)$ and it spreads over the entire component. This phenomenon degrades seriously the electrical performances of the HBT.
\end{abstract}

Keywords: SiGe HBT, RF modeling, COMSOL, Self-heating, Fraction of germanium.

DOI: 10.21272/jnep.12(6).06001

PACS numbers: 85.30.Pq, 71.20.Nr

\section{INTRODUCTION}

Communication systems have become an important issue for our daily activities [1,2]. This development would never have been possible without the constant development of new technology sectors. In order to best meet the requirements of communication systems, a good part of these channels have been adjusted towards improving operating frequencies as well as reducing noise levels of both semiconductor devices and electronic circuits [3].

At the moment, components with heterojunction remain the best positioned candidates to accomplish this demand for functional frequency and low noise level [4]. The development of $\mathrm{Si} / \mathrm{SiGe}$ heterojunction bipolar transistor (HBT) technologies that shows high potentialities in terms of cutoff frequency provides real possibilities for creating too fast electronic circuits [5-7]. Indeed, SiGe alloys offer a fundamental interest for the components studied, since they have a smaller band gap than silicon. Therefore, the contribution of germanium to the base of bipolar transistors allows reworking the energy bands of silicon.

Nowadays, these silicon-germanium technologies allow integration of the complete radio frequency systems on a single chip at low cost [8]. The bipolar transistors of these sectors are undeniably capable of getting transition frequencies of the order of $\mathrm{THz}$ [9], thus ensuring the functions achievement of a radio frequency domain such as amplification, mixing, analog and digital frequency division, phase/frequency analog and digital comparison.

This new technology attitude, at high frequencies, has imposed the presence of bipolar technologies, notably BiCMOS technology [10]. It uses both bipolar [11] and MOS [12] transistors, and thus gain the ad- vantages of both types of the components: high operating frequencies and low noise for the first, high integration density and low power consumption for the second [13]. In fact, the bipolar transistors of this segment (BiCMOS) are able to attain transition frequencies above $300 \mathrm{GHz}$ [14]. The introduction of germanium into the base of a SiGe HBT affects the component electrical properties, particularly self-heating and internal dissipation of heat in the component [15].

In order to observe the impact of the germanium percentage of the self-heating effect of the transistor, we simulated the static and dynamic characteristics of a $\mathrm{Si}_{1-x} \mathrm{Ge}_{x}$ HBT by varying germanium levels $(x=10 \%$, $20 \%, 30 \%$ ) with and without self-heating. We subsequently analyzed the heat distribution on the component surface for three germanium levels.

\section{SIMULATED STRUCTURE AND METHODOLOGY}

The studied structure is a SiGe $n-p-n$ HBT integrated in BiCMOS9 $0.13 \mu \mathrm{m}$ segment with a poly-silicon emitter (Fig. 1a).

Fig. $1 \mathrm{~b}$ shows a vertical doping profile of an $n-p-n$ HBT with a base. This structure has a maximum base doping concentration of $6 \cdot 10^{18} \mathrm{~cm}^{-3}$ with a fraction $x$ of germanium. This quantity is ranging from $x=10 \%$, $20 \%$ to $x=30 \%$. A maximum concentration of $1.5 \cdot 10^{21} \mathrm{~cm}^{-3}$ is fixed at the poly/mono interface emitter, a poly-silicon thickness of $600 \mathrm{~nm}$ and a doping level of $3 \cdot 10^{16} \mathrm{~cm}^{-3}$ are considered.

To simulate self-heating of a HBT, we used the commercial software COMSOL Multiphysics especially semiconductor interface and the HTS (Heat Transfer in Solids) module.

\footnotetext{
* abdelaaziz89boulgheb@gmail.com
} 

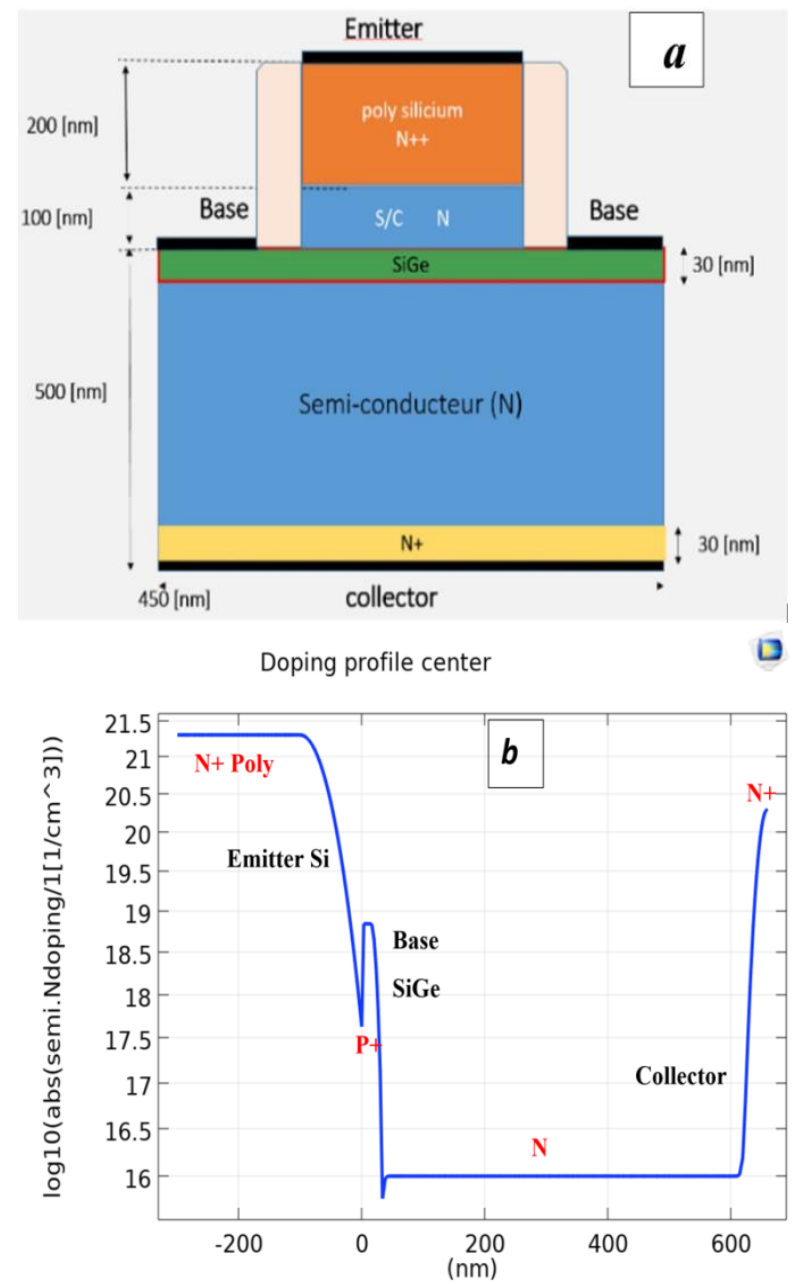

Fig. 1 - Simulated structure of a SiGe HBT [16] (a); simulated doping profile of a SiGe HBT (b)

The main equations are macroscopic semiconductor equations that use a Drive-Diffusion Model (DDM). It consists in solving both the Poisson equation and the electron and hole continuity equations. It is a coupled system with partial derivatives [17].

\subsection{Equations}

The Poisson equation is

$$
\nabla\left(-\varepsilon_{r} V \nabla\right)=q\left(P-N+N_{D}^{+}+N_{A}^{-}\right),
$$

and the continuity equations of current are

$$
\begin{aligned}
& \frac{\partial n}{\partial t}=\frac{1}{q}\left(\nabla J_{n}\right)-U_{n}, \\
& \frac{\partial p}{\partial t}=\frac{1}{q}\left(\nabla J_{p}\right)-U_{p} .
\end{aligned}
$$

Within the Poisson equation, $N_{D}^{+}$and $N_{A}^{-}$are concentrations of ionized impurities, $\varepsilon_{r}$ is the relative permittivity of the material and $q$ is the magnitude of a charge associated with an electron or a hole.

$$
J_{n}=-q N u_{n} \frac{d \phi_{n}}{d x}
$$

$$
J_{p}=-q P u_{p} \frac{d \phi_{p}}{d x} .
$$

The current densities of electrons and holes $J_{n}$ and $J_{p}$ depend on the concentrations $(N, P)$, carrier mobility $\left(u_{n}, u_{p}\right)$, as well as the quasi-Fermi potentials of electrons and holes $\left(\phi_{n}, \phi_{p}\right)$.

The physical simulation models adapted SiGe alloy are given by equations below. The band gap $\left(E_{g}\right)$ depends on the germanium ratio in this alloy $(x=10 \%$, $20 \%, 30 \%$ ) and the temperature according to the law below given by Thurmond. $E_{g 0}$ is the band gap width at a temperature $T_{0}=300 \mathrm{~K}, a(\mathrm{eV} / \mathrm{K})$ and $\beta(\mathrm{K})$ are two constants, which depend on the germanium percentage and temperature [18]

$$
\begin{gathered}
E_{g}\left(S i_{1-x} G e_{x}\right)=1.12-0.96 x+0.43 x^{2}-0.17 x^{3}, \\
E_{g}=E_{g}\left(T_{0}=300 K\right)+a\left(\frac{300^{2}}{300+\beta}-\frac{T^{2}}{T+\beta}\right),
\end{gathered}
$$

Mobility also depends on the value of the acceptor dopants $N_{A}$ and donors $N_{D}$, as well as temperature $T$. An empirical relationship associates mobility to these three parameters [19]:

$$
\begin{aligned}
& u_{n, a r}=u_{n, \min }-\frac{u_{n, 0}}{1+\left(\frac{N}{N_{n, 0}}\right)^{a_{n}}}, \\
& u_{p, a r}=u_{p, \min }-\frac{u_{p, 0}}{1+\left(\frac{N}{N_{p, 0}}\right)^{a_{p}}} .
\end{aligned}
$$

This system of equations allows to analyze the electrical behavior of semiconductors using COMSOL software.

However, in order to model the self-heating phenomenon in SiGe HBT, we consider another formulation which couples the semiconductor module with the HTS module

$$
\begin{aligned}
& J_{n}=q n u_{n} \nabla E_{C}+u_{n} k_{B} T \nabla n+q n D_{p, t h} \nabla \operatorname{lin}(T), \\
& J_{p}=q p u_{p} \nabla E_{V}+u_{p} k_{B} T \nabla p+q p D_{p, t h} \nabla \operatorname{lin}(T),
\end{aligned}
$$

where $E_{C}$ and $E_{V}$ are the energies of the conduction and valence bands and $D_{n}, D_{p}$ and $D_{n, t h}, D_{p, t h}$ are the constant thermal diffusions of electrons and holes.

Furthermore, the HTS module integrates the heat equation [20]:

$$
\begin{gathered}
\rho C_{p} \frac{\partial T}{\partial t}+\rho C_{p} u+\nabla q=Q, \\
q=k \nabla T,
\end{gathered}
$$

where $\rho\left(\mathrm{kg} / \mathrm{m}^{3}\right)$ is the solid density, $C_{p}(\mathrm{~J} / \mathrm{kg})$ is the solid heat capacity at a constant pressure, $u(\mathrm{~m} / \mathrm{s})$ is the defined velocity field, $Q\left(\mathrm{~W} / \mathrm{m}^{3}\right)$ is the heat source, $k$ $(\mathrm{W} /(\mathrm{m} \cdot \mathrm{K}))$ is the thermal conductivity of a solid [21, 22].

The system resolution forms a nonlinear coupled system that can only be solved by numerical methods of discretization COMSOL which use the finite element method. 


\section{RESULTS}

We can see in Fig. 2 the static gain $\beta$ of the HBT in the temperature case $(300 \mathrm{~K})$ and with self-heating $(T)$ for percentage of germanium $x$ of the order of $10 \%$, $20 \%, 30 \%$. By increasing the percentage of germanium of the order of $10 \%, 20 \%, 30 \%$, we notice a shift of the saturation point with the increase in the percentage of germanium. This shift is of the order of $0.1 \mathrm{~V}$, in the case of self-heating. The value of this offset becomes larger, in addition, the value of the static gain is $\beta=1350$ when the percentage of germanium $x=20 \%$.

The higher the germanium content of the alloy, the more the physical properties of the material change and approach those of germanium, which modifies the electrical characteristics of the SiGe HBT component. On the other hand, it can also be recorded that at high polarization, the more the Ge rate increases, the more problems we will have with high injection for lower $V_{b e}$. This indicates that the use of high Ge rates causes major problems of crystalline disorder as well as selfalignment between the emitter and the base.

In addition, we are interested in raising the temperature distribution over the entire surface of a SiGe HBT by varying the germanium fractions (10\%, $20 \%$, and $30 \%$ ) basically on the SiGe HBT to determine the hottest device zones.

The temperature distribution over the entire component surface is illustrated in Fig. 3 for the three germanium rates, namely, $10 \%, 20 \%$ and $30 \%$. We note that in case of the germanium fraction $x=10 \%$, the hottest point of self-heating is at the junction base/collector at a distance of $500 \mathrm{~nm}$ with a maximum temperature $T_{\max }=377 \mathrm{~K}$.

On the other hand, for germanium of $x=20 \%$, hot point approaches the collector substrate with a distance $d_{\text {self-heat }}=450 \mathrm{~nm}$ and a reduction in the self-heating value $\left(T_{\max }=366 \mathrm{~K}\right)$.

In this case, if the germanium fraction increases to $x=30 \%$, the hot point spreads on the entire surface (collector, base, emitter) with a component self-heating reduction. This corresponds to a decrease in the maximum temperature $\left(T_{\max }=354 \mathrm{~K}\right)$.

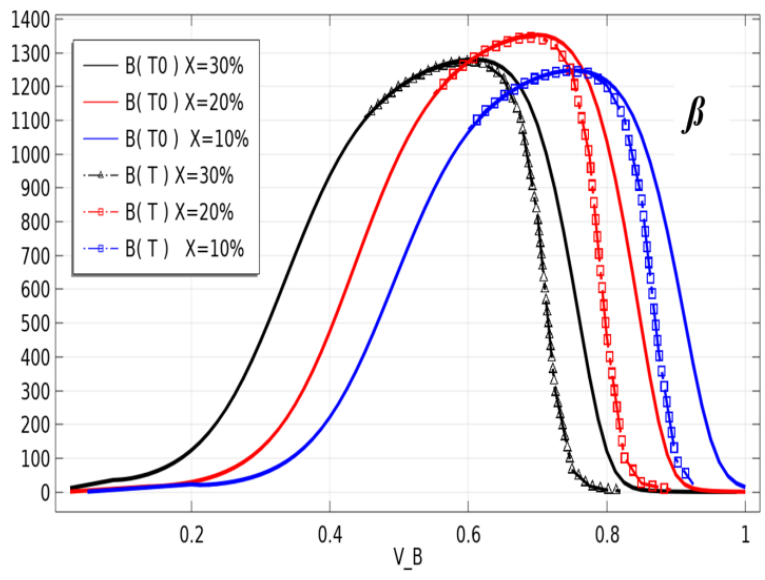

Fig. 2 - Static gain $(\beta)$ without self-heating $\left(T_{0}=300 \mathrm{~K}\right)$ and with self-heating $(T)$ of a SiGe HBT with a germanium rate $x$ varying from $10 \%, 20 \%$ to $30 \%$
Fig. 4 illustrates this propagation of the hottest point as a function with germanium rates.
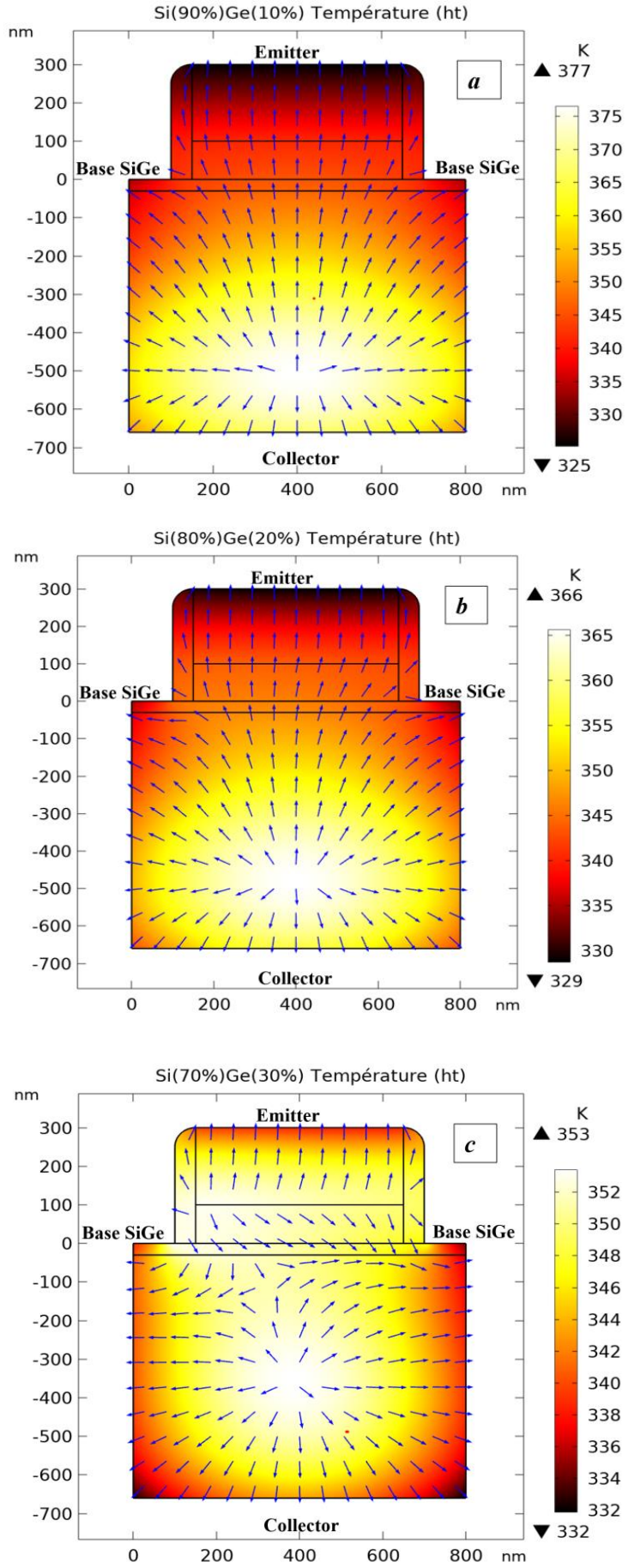

Fig. 3 - Temperature distribution in a $\mathrm{Si}_{1-x} \mathrm{Ge}_{x}$ HBT with germanium levels $x=10,20,30 \%$ : a) $x=10 \%$ and $T_{\max }=377 \mathrm{~K}$, b) $x=20 \%, T_{\max }=366 \mathrm{~K}$ and c) $x=30 \%, T_{\max }=354 \mathrm{~K}$

The table below summarizes the most important results of this study, namely, the germanium fraction effect on self-heating based on a $\mathrm{Si}_{1-x} \mathrm{Ge}_{x} \mathrm{HBT}$. It is suitable not to increase the germanium level in the alloy since it degrades the electrical characteristics of the component. 


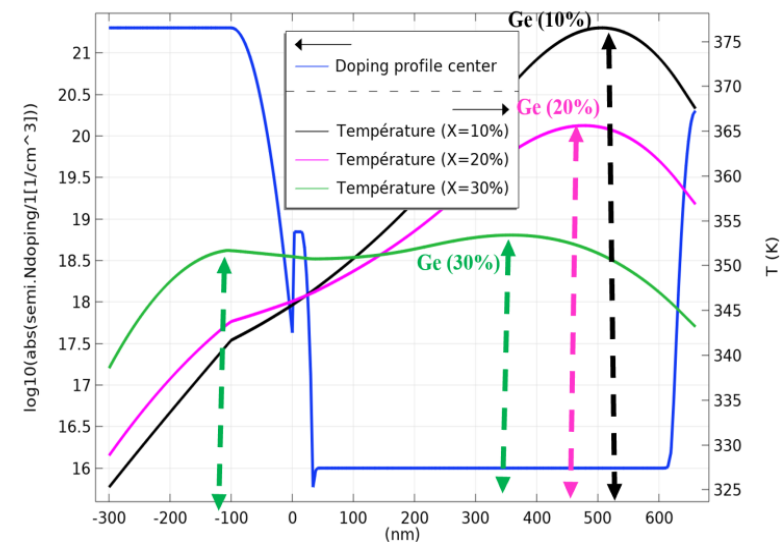

Fig. 4 - Temperature profiles considering a $\mathrm{Si}_{1-x} \mathrm{Ge}_{x}$ HBT with germanium rates $x$ varying from $x=10 \%, 20 \%$ to $30 \%$
We record an improvement in terms of the static gain of a HBT, when the germanium level increases $(x=10 \%$ and $x=20 \%$ ), and a decrease in the static gain when the germanium level attains $x=30 \%$, resulting in a displacement of the hottest point and its propagation on the entire structure (collector, base, emitter).

\section{CONCLUSIONS}

This work aims to analyze the self-heating phenomenon with germanium levels in SiGe based on an $n-p-n$ heterojunction bipolar transistor (HBT) integrated in a BiCMOS9 $0.13 \mu \mathrm{m}$ in order to determine its impact on the component electric performances using COMSOL Multiphysics commercial software and coupling the two semiconductor modules to the HTS (Heat Transfer in Solids) module.

Table 1 - Germanium fraction effect on the $\mathrm{Si}_{1-x} \mathrm{Ge}_{x} \mathrm{HBT}$

\begin{tabular}{|c|c|c|c|}
\hline $\begin{array}{c}\text { Germanium fraction } \\
\text { rate, } x\end{array}$ & $\begin{array}{c}\text { Auto warm-up, } \\
T_{\max }(\mathrm{K})\end{array}$ & $\begin{array}{c}\text { Static gain of self-heating, } \\
\beta_{\max }\end{array}$ & $\begin{array}{c}\text { Position of the } \\
\text { self-heating point }\end{array}$ \\
\hline $10 \%$ & $377 \mathrm{~K}$ & 1220 & $500 \mathrm{~nm}$ \\
\hline $20 \%$ & $366 \mathrm{~K}$ & 1350 & $450 \mathrm{~nm}$ \\
\hline $30 \%$ & $354 \mathrm{~K}$ & 1280 & $\begin{array}{c}\text { Propagation to collector, } \\
\text { base and emitter }\end{array}$ \\
\hline
\end{tabular}

We first simulated the static gain $(\beta)$ of a SiGe HBT without self-heating at a uniform temperature $T=300 \mathrm{~K}$ over the entire HBT structure for germanium fractions $(x=10 \%, 20 \%, 30 \%)$. Exceeding $20 \%$, the component characteristics are degraded as maximum gain decreases. In addition, we have analyzed the heat distribution of the component in order to observe the self-heating impact; and when the germanium rate increases, heat spreads over the entire HBT surface. It would therefore be suitable to choose a low germanium level (20\%) for minimizing the effects of self-heating in a SiGe-based HBT.

\section{REFERENCES}

1. J.Q. Li, S.Q. He, Z. Ming, S. Cai, J. Distributed Sensor: Networks. 11, 960173 (2015).

2. S. Chandrasekharan, K. Gomez, A. Al-Hourani, S. Kandeepan, T. Rasheed, L. Goratti, S. Allsopp, J. IEEE. Commun. Magazine 54(5), 26 (2016).

3. E. Seok, D. Shim, C. Mao, R. Han, S. Sankaran, C. Cao, W. Knap, J. IEEE. Solid. State. Circus 45(8), 1554 (2010).

4. C. Mukherjee, T. Jacquet, A. Chakravorty, T. Zimmer, J. Böck, K. Aufinger, C. Maneux, J. IEEE. Trans. Electron. Dev. 63, 3657 (2016).

5. P. Chevalier, M. Schröter, C. R. Bolognesi, V. d'Alessandro, M. Alexandrova, J. Böck, R. Lövblom, J. IEEE 105, 1035 (2017).

6. A. Pawlak, B. Heinemann, M. Schroter, J. IEEE. Bip/BiCMOS. Circus. Techno. (BCTM), 134 (2017).

7. N. Sarmah, J. Grzyb, K. Statnikov, S. Malz, P.R. Vazquez, W. Föerster, U.R. Pfeiffer, J. IEEE. Trans. 64, 562 (2015).

8. T. Georgantas, K. Vavelidis, N. Haralabidis, S. Bouras, I. Vassiliou, C. Kapnistis, N. Kanakaris, J. IEEE. Solid. State. Circus 1 (2015).

9. J. Grzyb, K. Statnikov, N. Sarmah, B. Heinemann, U.R. Pfeiffer, IEEE Trans. Terahertz Sci. Technol. 6, 771 (2016).

10. R.B. Yishay, O. Katz, B. Sheinman, R. Carmon, R. Levinger, N. Mazor, D. Elad, J. IEEE Rad. Freq. Integr. Circus. Symp, 417 (2015).

11. M. Sugiyama, H. Takemura, C. Ogawa, T. Tashiro, T. Morikawa, M. Nakamae, J. IEEE Electron. Dev. 221 (1989).
12. B. Hoeneisen, C.A. Mead, J. Solid. State. Electron. 15, 819 (1972).

13. T. Takemoto, Y. Matsuoka, Y. Sugiyama, H. Yonezawa, H. Yamashita, K. Adachi, K. Osada, IEEE Trans. Electron. Tu3G-2 (2015).

14. C. Jiang, A. Mostajeran, R. Han, M. Emadi, H. Sherry, A. Cathelin, E. Afshari, J. IEEE Solid. State. Circus 51, 2596 (2016).

15. C. Mukherjee, C.K. Maiti, J. Basic Appl. Phys. 3, 16 (2014).

16. A.K. Sahoo, Electro-thermal Characterizations, Compact Modeling and TCAD based Device Simulations of advanced SiGe:C BiCMOS HBTs and of nanometric CMOS FET, $\mathrm{PhD}$ Thesis, University Bordeaux 1, 214 (2012).

17. K.O. Petrosyants, R.A. Torgovnikov, J. IEEE 172 (2015).

18. C.K. Maiti, G.A. Armstrong, Applications of Silicon-Germanium Heterostructure Devices (CRC Press: 2001).

19. N.D. Arora, J.R. Hauser, D.J. Roulston, J. IEEE Trans. Electron. Dev. 29 No 2, 292 (1982).

20. S. Selberherr, Analysis and Simulation of Semiconductor Devices, 127 (Springer Verlag: 1984).

21. A. Bejan, Heat Transfer (John Wiley \& Sons: 1993).

22. T.L. Bergman, F.P. Incropera, D.P. DeWitt, A.S. Lavine, Fundamentals of heat and mass transfer, 6th Ed. (John Wiley \& Sons: 2011). 


\title{
Аналіз самонагрівання SiGe HBT, призначеного для ВЧ-застосувань, за процентним вмістом германію
}

\author{
A. Boulgheb, M. Lakhdara, N. Kherief, S. Latreche \\ Département d'Electronique, Faculté des Sciences de la Technologie, Laboratoire Hyperfréquences \& \\ Semi-conducteurs (LHS), Université des Frères Mentouri, Constantine, Algeria \\ Основною метою роботи є визначення впливу процентного вмісту германію в основі SiGe біполярно- \\ го транзистора з гетеропереходом (НВТ) для аналіза ефекта самонагрівання пристрою. Ми використо- \\ вуємо комерційне програмне забезпечення COMSOL Multiphysics. Модель пов'язує напівпровіднико- \\ вий модуль з модулем HTS (Heat Transfer in Solids). Це дозволяє моделювати розподіл температури на \\ пристрої SiGe HBT для рівнів германію в межах від $x=10 \%, 20 \%$ до $x=30$ \%. Спочатку ми визначаємо \\ статичний коефіціент підсилення ( $\beta$ ) SiGe HBT шляхом варіювання процентного вмісту германію. Крім \\ того, ми аналізуемо розподіл тепла на поверхні компонента для трьох розглянутих рівнів германію, \\ щоб визначити максимальну температуру $T_{\max }$ в пристрої. Дійсно, для $x=10$ \% максимальна темпера- \\ тура становить $T_{\max }=377 \mathrm{~K}$ і близька до переходу база-колектор. При збільшенні фракції германію в \\ сплаві $\mathrm{SiGe}(x=20 \%)$ максимальна температура самонагрівання зменшуеться $\left(T_{\max }=366 \mathrm{~K}\right)$, тоді як \\ при $x=30$ \% температура самонагрівання зменшується ще більше $\left.T_{\max }=354 \mathrm{~K}\right)$, і вона поширюеться на \\ весь компонент. Це явище серйозно погіршує електричні характеристики НВТ.
}

Ключові слова: SiGe HBT, BЧ-моделювання, COMSOL, Самонагрівання, Фракція германію. 